\title{
Is Ankyrin a genetic risk factor for psychiatric phenotypes?
}

Alejandro Gella ${ }^{1}$, Mònica Segura' ${ }^{1}$ Núria Durany ${ }^{1}$, Bruno Pfuhlmann², Gerald Stöber ${ }^{2}$ and Micha Gawlik ${ }^{2 *}$

\begin{abstract}
Background: Genome wide association studies reported two single nucleotide polymorphisms in ANK3 (rs9804190 and rs 10994336) as independent genetic risk factors for bipolar disorder. Another SNP in ANK3 (rs10761482) was associated with schizophrenia in a large European sample. Within the debate on common susceptibility genes for schizophrenia and bipolar disorder, we tried to investigate common findings by analyzing association of ANK3 with schizophrenia, bipolar disorder and unipolar depression.

Methods: We genotyped three single nucleotide polymorphisms (SNPs) in ANK3 (rs9804190, rs10994336, and rs 10761482) in a case-control sample of German descent including 920 patients with schizophrenia, 400 with bipolar affective disorder, 220 patients with unipolar depression according to ICD 10 and 480 healthy controls. Sample was further differentiated according to Leonhard's classification featuring disease entities with specific combination of bipolar and psychotic syndromes.

Results: We found no association of rs9804190 and rs10994336 with bipolar disorder, unipolar depression or schizophrenia. In contrast to previous findings rs 10761482 was associated with bipolar disorder $(p=0.015)$ but not with schizophrenia or unipolar depression. We observed no association with disease entities according to Leonhard's classification.
\end{abstract}

Conclusion: Our results support a specific genetic contribution of ANK3 to bipolar disorder though we failed to replicate findings for schizophrenia. We cannot confirm ANK3 as a common risk factor for different diseases.

\section{Background}

Schizophrenia and bipolar disorder are genetically complex diseases with numerous proposed genetic risk factors encompassing different pathophysiological pathways of neurotransmission, brain development or synaptic plasticity with each small contribution to disease risk and inconsistent results among replication studies (Stöber et. al 2009) [1,2]. Recently genome wide association studies (GWAs) lead to identification of new susceptibility genes with genome-wide levels of significance: zinc finger gene ZNF804A on chromosome $2 \mathrm{q} 32$ or the $M H C$-locus at 6 p21 on schizophrenia. For bipolar disorder the most promising results have been reported for $C A C N A 1 C$ and $A N K 3$ (ankyrin 3, node of Ranvier) [3-5]. Subsequently CACNA1C and ZNF804A were proposed as common risk variants for both bipolar disorder

\footnotetext{
* Correspondence: gawlik_m@klinik.uni-wuerzburg.de

${ }^{2}$ Department of Psychiatry, Psychosomatics and Psychotherapy, University of Würzburg, Füchsleinstraße 15, Würzburg-97080, Germany

Full list of author information is available at the end of the article
}

and schizophrenia and a Meta-analysis additionally added the $M H C$-locus as a common risk factor for both diseases [5].

ANK3 at 10q21.2 consists of 44 exons spanning 700 $\mathrm{kb}$ on genomic DNA with multiple splicing variants. A GWA study based on pooled DNA found association with bipolar disorder and rs9804190 located intronic between exon 36 and 37 at the locus ANK3 [6]. A Metaanalysis of GWA on bipolar patients with European ancestry reported an additional marker rs10994336, about $340 \mathrm{~kb}$ distal to rs9804190, at the 3-UTR of ANK3 [7]. Further analysis suggested that each variant might contribute independently to bipolar disorder [8]. A further SNP located 3-UTR showed suggestive evidence of genome-wide association in a Han Chinese sample [9]. Subsequent studies found a genetic marker at ANK3 to be associated with schizophrenia as well. Analysis in a GWA study of a Norwegian discovery sample with a large European replication sample reported association of rs10761482 located near 3-UTR between exon
C Biomed Central 
41 and 42 with disease at a distance of $84.5 \mathrm{~kb}$ to rs9804190 [10].

Ankyrin 3 is a brain expressed member of a proteinfamily linking the integral membrane proteins to the underlying spectrin-actin cytoskeleton. The gene product Ankyrin-G of 4377 amino acids locates on axonal initial segment and at nodes of Ranvier in the central and peripheral neurons. Ankyrin-G is proposed to play a regulatory role on sodium channel function, cell adhesion and neuronal development [11-16]. A post mortem study reported reduced immunoreactive of Ankyrin-G in pyramidal neurons in the superficial cortical layer of the dorsolateral prefrontal cortex in subjects with schizophrenia [17].

Within the debate on common susceptibility genes for schizophrenia and bipolar disorder we attempted to replicate common findings of a genetic association for different disease entities by analyzing association of ANK3 with major psychosis in a case-control study with SNPs rs9804190, rs10994336, and rs10761482. For diagnosis we used beside ICD10 Leonhard's classification separating disease entities with specific combination of bipolar and psychotic syndromes [18].

Karl Leonhard divides psychoses into five main groups, systematic schizophrenias, unsystematic schizophrenias and cycloid psychoses. Affective psychoses are subdivided into bipolar manic depression and monopolar depression. In family and twin studies based on Leonhard's classification, a different genetic background for each diagnostic category was demonstrated [19]

\section{Methods}

Index cases were recruited from the Department of Psychiatry, Psychosomatics and Psychotherapy at of the University of Würzburg. The sample encompassed 920 cases (631 males, 68\%) with psychosis according to ICD10 for schizophrenia or related diseases with an average age at onset of 26.5 years and an average age at recruitment of 41 years including 182 cases with schizoaffective disorder (ICD10 F20-F25). 400 cases (231 males, 58\%) with bipolar disorder (F30-F31) with an average age at onset of 32 years and an average age at recruitment of 42.5 years and 220 cases (134 males, $61 \%$ ) with unipolar depression (F32-F33). with an average age at onset of 43 years and an average age at recruitment of 51 years.

Sample was further subdivided according to Leonhard's classification systematic schizophrenias $(\mathrm{n}=228)$, unsystematic schizophrenias $(\mathrm{n}=635)$, cycloid psychosis ( $\mathrm{n}=309)$, manic depression $(\mathrm{n}=284)$ and monopolar depression $(n=90)$ [17]. Diagnosis in differentiated psychopathology was made by repeated personal examinations of experienced psychiatrists (BP, MG, GS).
The 480 volunteer control subjects (283 males, 59\%) were recruited from the blood donor centre at the University of Würzburg. The average age of recruitment was 29 years. The preponderance of males in both samples avoided gender distortion in comparison of cases and controls. All subjects were unrelated and of German Caucasian descent. The Ethics Committee of the University of Würzburg had approved the study, and written informed consent was obtained from all subjects.

PCR for allelic discrimination was performed in a final reaction volume of $20 \mu \mathrm{l}$ containing $20 \mathrm{ng}$ genomic DNA and $10 \mu \mathrm{l}$ of $2 \times$ TaqMan ${ }^{\circledR}$ Universal PCR Master Mix (Applied Biosystems) and $1 \mu \mathrm{l}$ of $20 \times$ TaqMan $^{\mathrm{TM}}$ SNP genotyping assay including fluorescent tags specific for the wild type allele and the variant allele. Marker amplification was performed in microtiter plates on Biometra thermocyclers (Whatman). PCR amplification conditions were according to the manufacturer's recommendation $\left[10 \mathrm{~min}\right.$ at $95^{\circ} \mathrm{C}$ followed by $15 \mathrm{sec}$ at $92^{\circ} \mathrm{C}$ and $60 \mathrm{sec}$ at $60^{\circ} \mathrm{C}$ for 40 cycles]. Allelic discrimination with endpoint detection of fluorescence was performed at $60^{\circ} \mathrm{C}$ on an $\mathrm{ABI}$ prism 7000 sequence detection system followed by analysis with an appropriate software package (Applied Biosystems). All genotype experiments were made at least in duplicate, with quality control of automated allele calling by two independent operators blind to phenotype. The calling rate was $99 \%$.

Software FAMHAP was used to test for association [20]. Hardy-Weinberg equilibrium (HWE) and pairwise standardized linkage disequilibrium (LD) were calculated with the program HAPLOVIEW [21]. The software "stastical power calculator" was used analyzing power for association test [22].

\section{Results}

Corresponding to HAPMAP data rs9804190 locates between LD-block 7 and 8, rs10761482 in LD-block 26 and rs10994336 in a downstream LD block of ANK3. Thus, linkage disequilibrium (LD) was low between the analyzed markers with LD' 0.018 between rs9804190 and rs10761482, 0.0060 between rs9804190 and rs10994336 and 0.72 between rs10761482 and rs10994336 located at 3'-UTR. All SNPs were in HWE.

Analyzing Allele and genotype frequencies in cases according to the ICD 10 classification with schizophrenia, bipolar disorder or major depression revealed no association for SNPs rs9804190 and rs10994336, (table 1 and 2). We observed no significant difference between cases and controls for subgroup with schizoaffective disorder. SNP rs10761482 was associated with bipolar disorder $(\mathrm{p}=0.015$, OR 1.304 , CI $1.065-1.595)$ but not with schizophrenia, nor with subgroup schizoaffective disorder nor with unipolar depression (table 1 and 2). 
Table 1 Bipolar disorder according to ICD10: Genotype distribution and test for association

\begin{tabular}{cccccccccccc}
\hline & Cases & Controls & Cases & Controls & \multicolumn{2}{c}{ Cases } & Controls & \multicolumn{3}{c}{ Cases } & \multicolumn{2}{c}{ Controls } \\
SNP & $\mathbf{n}$ & $\mathbf{n}$ & $\mathbf{C C}$ & $\mathbf{C C}$ & $\mathbf{P}$ & $\mathbf{C T}$ & $\mathbf{C T}$ & $\mathbf{P}$ & $\mathbf{T T}$ & TT & P \\
\hline rs9804190 (C/T) & 400 & 480 & 0.618 & 0.578 & 0.237 & 0.327 & 0.380 & 0.101 & 0.056 & 0.042 & 0.337 \\
rs10994336 (C/T) & 400 & 480 & 0.843 & 0.874 & 0.182 & 0.154 & 0.119 & 0.13 & 0.003 & 0.006 & 0.415 \\
rs10761482 (C/T) & 400 & 480 & 0.652 & 0.572 & 0.015 & 0.300 & 0.359 & 0.063 & 0.048 & 0.069 & 0.19 \\
\hline
\end{tabular}

P: test for association (FAMHAP); CC, CT, TT: genotypes

Sample was further differentiated according to Leonhard's classification. Analyzing association of SNPs with schizophrenic spectrum divided into subgroups systematic schizophrenias, unsystematic schizophrenias and cycloid psychosis provided no significance. Likewise affective diseases with manic depression and monopolar depression reached no significant association.

Analyzing haplotype with FAMHAP provided no further risks haplotype concordant with observed low LD.

Our study population with 1540 cases and 480 controls had a power of $55.1 \%$ to replicate the reported association with bipolar disorder and of $69.1 \%$ with schizophrenia (alpha $=0.05 \%$ ).

\section{Discussion}

Common susceptibility genes for schizophrenia and bipolar disorder challenge traditional diagnostic categories and boundaries between schizophrenia and bipolar disorder. We attempt to replicate genetic association findings of $A N K 3$ as a possible common risk factor for schizophrenia and affective disorders in a case control study of > 2000 subjects of German descent. Analysis of previous associated SNPs in different LD-Blocks, located intronic (rs9804190 and rs10761482) or $30 \mathrm{~kb}$ downstream of ANK3 (rs10994336) found a nominally significant association of SNP rs10761482 with bipolar disorder $(\mathrm{p}=0.015$, OR 1.304$)$ but not with schizophrenia (table 1 and 2). Thus, association of this marker with schizophrenia in a GWA analysis of European samples could not be confirmed [16].

We failed to confirm an association of rs9804190 and rs10994336 with bipolar disorder reported in two previous GWA studies. We found no association with unipolar depression or schizophrenia including subgroup of schizoaffective disorder (table 1 and 2) [13,14]. Analyzing haplotype provided no further risks haplotype concordant with observed low LD between the markers.

Our failure to replicate previous findings could be due to insufficient sample size. The study had a power of $55.1 \%$ to replicate reported association with bipolar disorder and of $69.1 \%$ with schizophrenia (alpha $=0.05 \%$ ) $[14,16]$. However, in our study were cases and controls of the same genetic background, minimizing a distortion regarding genetic heterogeneity. The strength of our strategy is the combination of operational diagnostic criteria (ICD-10) and Leonhard's categorical diagnostic approach. In search for common risk factors for schizophrenia and bipolar disorder we found no association in the schizophrenic spectrum neither with systematic schizophrenias nor with subgroups with a specific combination of bipolar and psychotic syndromes: Particularly the unsystematic schizophrenias and strictly defined manic depression with strong genetic background $[19,23,24]$. Other disease entities according to Leonhard's classification were not associated to any of the markers.

Our data support findings from two meta-analyses of GWA-studies searching for common risk variants in ANK3 for schizophrenia, bipolar disorder or unipolar depression: One study combining Meta-analysis and additional genotyping of a bipolar and unipolar sample from the US, the UK, Ireland, and Netherlands, found no association of variants in ANK3 and unipolar depression. Another Meta-analysis on GWA studies based on schizophrenia and bipolar disorder cohorts with samples from UK observed no significant results for schizophrenia. Both Meta-analyses suggested a specific effect of ANK3 for bipolar disorder [25,5].

Since genetically associated SNPs around ANK3 are intronic or in downstream regions located, causative coding variants or associated haplotype blocks are still

Table 2 Schizophrenia according to ICD10: Genotype distribution and test for association

\begin{tabular}{|c|c|c|c|c|c|c|c|c|c|c|c|}
\hline & Cases & Controls & Cases & Controls & & Cases & Controls & & Cases & Controls & \\
\hline SNP & $\mathrm{n}$ & $\mathbf{n}$ & $\mathrm{CC}$ & CC & $\mathbf{P}$ & CT & CT & $\mathbf{P}$ & $T T$ & TT & $\mathbf{P}$ \\
\hline rs9804190 (C/T) & 920 & 480 & 0.577 & 0.578 & 0.949 & 0.369 & 0.380 & 0.674 & 0.055 & 0.042 & 0.284 \\
\hline rs10994336 (C/T) & 920 & 480 & 0.884 & 0.874 & 0.617 & 0.112 & 0.119 & 0.689 & 0.004 & 0.006 & 0.62 \\
\hline rs10761482 (C/T) & 920 & 480 & 0.557 & 0.572 & 0.593 & 0.394 & 0.359 & 0.196 & 0.048 & 0.069 & 0.113 \\
\hline
\end{tabular}

P: test for association (FAMHAP); CC, CT, TT: genotypes 
missing. Regard distorted gene regulation as patho-physiological causative factor a recent study reported evidence for cis-acting regulation of $A N K 3$ by testing for allelic expression imbalance, but the study failed to attribute dysregulation to risk-associated SNPs [26].

\section{Conclusions}

In conclusion, our results support a genetic contribution of ANK3 to ICD 10 bipolar disorder, though we failed to replicate findings for schizophrenia according to ICD 10 or Leonhard's classification. Our study cannot confirm $A N K 3$ as a common risk factor for both diseases, challenging the hypothesis that bipolar disorder and schizophrenia are just different phenotypes of the same disease.

\section{Acknowledgements}

This work was supported by grant PSEP2009 from the International Federation of Clinical Chemistry (IFCC) and by grant FI2009-00229 from the Generalitat de Catalunya. We thank Nalisoa Randriamahefa for her excellent technical assistance. We also thank DFG for support.

\section{Author details}

${ }^{1}$ Faculty of Medicine and Health Sciences, Universitat Internacional de Catalunya, Josep Trueta s/n, Sant Cugat del Vallès-08195, Spain. ${ }^{2}$ Department of Psychiatry, Psychosomatics and Psychotherapy, University of Würzburg, Füchsleinstraße 15, Würzburg-97080, Germany.

\section{Authors' contributions}

AG and MS performed the experiments and drafted the manuscript, ND and GS conceived the study and participated in the coordination. BP and GS carried out the diagnostic evaluation of the patients; MG carried out the statistical analyses, coordinated the study and wrote the manuscript. All authors read and approved the final manuscript.

\section{Authors' information}

To our deep regret Professor Núria Durany passed away on August 27th 2010 after an intense but short fighting an illness. We shall continue to cherish her passion for science.

\section{Competing interests}

The authors declare that they have no competing interests.

Received: 13 December 2010 Accepted: 24 June 2011

Published: 24 June 2011

\section{References}

1. Allen NC, Bagade S, McQueen MB, loannidis JP, Kavvoura FK, Khoury MJ, Tanzi RE, Bertram L: Systematic meta-analyses and field synopsis of genetic association studies in schizophrenia: the SzGene database. Nat Genet 2008, 40:827-834.

2. Stöber G, Ben-Shachar D, Cardon M, Falkai P, Fonteh AN, Gawlik M, Glenthoj BY, Grunblatt E, Jablensky A, Kim YK, Kornhuber J, McNeil TF, Muller N, Oranje B, Saito T, Saoud M, Schmitt A, Schwartz M, Thome J, Uzbekov M, Durany N, Riederer P: Schizophrenia: From the brain to peripheral markers. A consensus paper of the WFSBP task force on biological markers. World Journal of Biological Psychiatry 2009, 10:127-155.

3. Stefansson H, Ophoff RA, Steinberg S, Andreassen OA, Cichon S, Rujescu D, Werge T, Pietiläinen OP, Mors O, Mortensen PB, Sigurdsson E, Gustafsson O, Nyegaard M, Tuulio-Henriksson A, Ingason A, Hansen T, Suvisaari J, Lonnqvist J, Paunio T, Børglum AD, Hartmann A, Fink-Jensen A, Nordentoft M, Hougaard D, Norgaard-Pedersen B, Böttcher $Y$, Olesen J, Breuer R, Möller HJ, Giegling I, Rasmussen HB, Timm S, Mattheisen M, Bitter I, Réthelyi JM, Magnusdottir BB, Sigmundsson T, Olason P, Masson G, Gulcher JR, Haraldsson M, Fossdal R, Thorgeirsson TE, Thorsteinsdottir U,
Ruggeri M, Tosato S, Franke B, Strengman E, Kiemeney LA, Genetic Risk and Outcome in Psychosis (GROUP), Melle I, Djurovic S, Abramova L, Kaleda V, Sanjuan J, de Frutos R, Bramon E, Vassos E, Fraser G, Ettinger U, Picchioni M, Walker N, Toulopoulou T, Need AC, Ge D, Yoon JL, Shianna KV, Freimer NB, Cantor RM, Murray R, Kong A, Golimbet V, Carracedo A, Arango C, Costas J, Jönsson EG, Terenius L, Agartz I, Petursson H, Nöthen MM, Rietschel M, Matthews PM, Muglia P, Peltonen L, St Clair D, Goldstein DB, Stefansson K, Collier DA: Common variants conferring risk of schizophrenia. Nature 2009, 460:744-7.

4. O'Donovan MC, Craddock N, Norton N, Williams H, Peirce T, Moskvina V, Nikolov I, Hamshere M, Carroll L, Georgieva L, Dwyer S, Holmans P, Marchini JL, Spencer CC, Howie B, Leung HT, Hartmann AM, Möller HJ, Morris DW, Shi Y, Feng G, Hoffmann P, Propping P, Vasilescu C, Maier W, Rietschel M, Zammit S, Schumacher J, Quinn EM, Schulze TG, Williams NM, Giegling I, Iwata N, Ikeda M, Darvasi A, Shifman S, He L, Duan J, Sanders AR, Levinson DF, Gejman PV, Cichon S, Nöthen MM, Gill M, Corvin A, Rujescu D, Kirov G, Owen MJ, Buccola NG, Mowry BJ, Freedman R, Amin F, Black DW, Silverman JM, Byerley WF, Cloninger CR, Molecular Genetics of Schizophrenia Collaboration: Identification of loci associated with schizophrenia by genome-wide association and follow-up. Nat Genet 2008, 40:1053-5.

5. Williams HJ, Craddock N, Russo G, Hamshere ML, Moskvina V, Dwyer S, Smith RL, Green E, Grozeva D, Holmans P, Owen MJ, O'Donovan MC: Most genome-wide significant susceptibility loci for schizophrenia and bipolar disorder reported to date cross-traditional diagnostic boundaries. Hum Mol Genet 2011, 20:387-91.

6. Baum AE, Akula N, Cabanero M, Cardona I, Corona W, Klemens B, Schulze TG, Cichon S, Rietschel M, Nöthen MM, Georgi A, Schumacher J, Schwarz M, Abou Jamra R, Höfels S, Propping P, Satagopan J, Detera-Wadleigh SD, Hardy J, McMahon FJ: A genomewide association study implicates diacylglicerol kinase (DGKH) and several other genes in the etiology of bipolar disorder. Mol Psychiatry 2008, 13:197-207.

7. Ferreira MA, O'Donovan MC, Meng YA, Jones IR, Ruderfer DM, Jones L, Fan J, Kirov G, Perlis RH, Green EK, Smoller JW, Grozeva D, Stone J, Nikolov I, Chambert K, Hamshere ML, Nimgaonkar V, Moskvina V, Thase ME, Caesar S, Sachs GS, Franklin J, Gordon-Smith K, Ardlie KG, Gabriel SB, Fraser C, Blumenstiel B, Defelice M, Breen G, Gill M, Morris DW, Elkin A, Muir WJ, McGhee KA, Williamson R, MacIntyre DJ, McLean A, St Clair D, VanBeck M, Pereira A, Kandaswamy R, McQuillin A, Collier DA, Bass NJ, Young AH, Lawrence J, Ferrier IN, Anjorin A, Farmer A, Curtis D, Scolnick EM, McGuYn P, Daly MJ, Corvin AP, Holmans PA, Blackwood DH, Wellcome Trust Case Control Consortium (WTCCC), Gurling HM, Owen MJ, Purcell SM, Sklar P, Craddock NJ: Collaborative genome-wide association analysis supports a role for ANK3 and CACNA1C in bipolar disorder. Nat Genet 2008, 40:1056-1058.

8. Schulze TG, Detera-Wadleigh SD, Akula N, Gupta A, Kassem L, Steele J, Pearl J, Strohmaier J, Breuer R, Schwarz M, Propping P, Nothen MM, Cichon S, Schumacher J, Rietschel M, McMahon FJ: Two variants in Ankyrin 3 (ANK3) are independent genetic risk factors for bipolar disorder. Mol Psychiatry 2009, 14:487-491.

9. Lee MT, Chen CH, Lee CS, Chen CC, Chong MY, Ouyang WC, Chiu NY Chuo L, Chen CY, Tan HK, Lane HY, Chang TJ, Lin CH, Jou SH, Hou YM, Feng J, Lai TJ, Tung CL, Chen TJ, Chang CJ, Lung FW, Chen CK, Shiah IS, Liu CY, Teng PR, Chen KH, Shen LJ, Cheng CS, Chang TP, Li CF, Chou CH, Chen CY, Wang KH, Fann CS, Wu JY, Chen YT, Cheng AT: Genome-wide association study of bipolar I disorder in the Han Chinese population. Mol Psychiatry 2011, 16:548-56.

10. Athanasiu L, Mattingsdal M, Kähler AK, Brown A, Gustafsson O, Agartz I, Giegling I, Muglia P, Cichon S, Rietschel M, Pietiläinen OP, Peltonen L, Bramon E, Collier D, Clair DS, Sigurdsson E, Petursson H, Rujescu D, Melle I, Steen VM, Djurovic S, Andreassen OA: Gene variants associated with schizophrenia in a Norwegian genome-wide study are replicated in a large European cohort. J Psychiatr Res 2010, 44:748-53.

11. Bennett $V$, Lambert $S$ : Physiological roles of axonal ankyrins in survival of premyelinated axons and localization of voltage-gated sodium channels. Journal of Neurocytology 1999, 28:303-318.

12. Kretschmer T, England JD, Happel LT, Liu ZP, Thouron CL, Nguyen DH Beuerman RW, Kline DG: Ankyrin G and voltage gated sodium channels colocalize in human neurona - key proteins of membrane remodeling after axonal injury. Neuroscience Letters 1999, 323:151-155. 
13. Dzhashiashvili Y, Zhang Y, Galinska J, Lam I, Grumet M, Salzer JL: Nodes of Ranvier and axon initial segments are ankyrin G-dependent domains that assemble by distinct mechanisms. J Cell Biol 2007, 177:857-70.

14. Kizhatil K, Davis JQ, Davis L, Hoffman J, Hogan BL, Bennett V: Ankyrin-G is a molecular partner of E-cadherin in epithelial cells and early embryos. J Biol Chem 2007, 282:26552-61.

15. Jenkins SM, Bennett V: Developing nodes of Ranvier are defined by ankyrin-G clustering and are independent of paranodal axoglial adhesion. Proc Natl Acad Sci USA 2002, 99:2303-8.

16. Jenkins SM, Bennett $V$ : Ankyrin-G coordinates assembly of the spectrinbased membrane skeleton, voltage-gated sodium channels, and L1 CAMs at Purkinje neuron initial segments. J Cell Biol 2001, 155:739-46.

17. Cruz DA, Weaver CL, Lovallo EM, Melchitzky DS, Lewis DA: Selective alterations in postsynaptic markers of chandelier cell inputs to cortical pyramidal neurons in subjects with schizophrenia. Neuropsychopharmacology 2009, 34:12-24.

18. Leonhard K: Classification of endogenous psychoses and their differentiated etiology. enlarged, Wien, New York Springer; 21999

19. Franzek $E$, Beckmann $H$ : Different genetic background of schizophrenia spectrum psychoses: a twin study. Am J Psychiatry 1998, 155:76-83.

20. Becker T, Knapp M: Maximum-likelihood estimation of haplotype frequencies in nuclear families. Genet Epidemiol 2004, 27:21-32.

21. Barrett JC, Fry B, Maller J, Daly MJ: Haploview: analysis and visualization of LD and haplotype maps. Bioinformatics 2005, 21:263-5.

22. stastical power calculator. [http://www.dssresearch.com/toolkit/spcalc/ power.asp].

23. Pfuhlmann B, Jabs B, Althaus G, Schmidtke A, Bartsch A, Stöber G, Beckmann H, Franzek E: Cycloid psychoses are not part of a bipolar affective spectrum: results of a controlled family study. J Affect Disord 2004, 83:11-9.

24. Stöber G, Franzek E, Lesch KP, Beckmann H: Periodic catatonia: a schizophrenic subtype with major gene effect and anticipation. Eur Arch Psychiatry Clin Neurosci 1995, 245:135-41.

25. Liu Y, Blackwood DH, Caesar S, de Geus EJ, Farmer A, Ferreira MA, Ferrier IN, Fraser C, Gordon-Smith K, Green EK, Grozeva D, Gurling HM, Hamshere ML, Heutink P, Holmans PA, Hoogendijk WJ, Hottenga JJ, Jones L, Jones IR, Kirov G, Lin D, McGuffin P, Moskvina V, Nolen WA, Perlis RH, Posthuma D, Scolnick EM, Smit AB, Smit JH, Smoller JW, St Clair D, van Dyck R, Verhage M, Willemsen G, Young AH, Zandbelt T, Boomsma DI, Craddock N, O'Donovan MC, Owen MJ, Penninx BW, Purcell S, Sklar P, Sullivan PF: Metaanalysis of genome-wide association data of bipolar disorder and major depressive disorder. Mol Psychiatry 2011, 16:2-4.

26. Quinn EM, Hill M, Anney R, Gill M, Corvin AP, Morris DW: Evidence for cisacting regulation of ANK3 and CACNA1C gene expression. Bipolar Disord 2010, 12:440-5.

\section{Pre-publication history}

The pre-publication history for this paper can be accessed here: http://www.biomedcentral.com/1471-244X/11/103/prepub

doi:10.1186/1471-244X-11-103

Cite this article as: Gella et al:: Is Ankyrin a genetic risk factor for psychiatric phenotypes? BMC Psychiatry 2011 11:103.

\section{Submit your next manuscript to BioMed Central and take full advantage of:}

- Convenient online submission

- Thorough peer review

- No space constraints or color figure charges

- Immediate publication on acceptance

- Inclusion in PubMed, CAS, Scopus and Google Scholar

- Research which is freely available for redistribution

Submit your manuscript at www.biomedcentral.com/submit
Biomed Central 